\title{
Minor Restrictions: Adolescence Across Legal Disciplines, the Infancy Doctrine, and the Restatement (Third) of Restitution and Unjust Enrichment
}

\author{
Cheryl B. Preston ${ }^{*}$ \& Brandon T. Crowther ${ }^{* *}$
}

\section{INTRODUCTION}

Teens have emerged as a powerful market segment, especially with respect to online goods and services. In 2011, they commanded an estimated $\$ 91.1$ billion in buying power. ${ }^{1}$ As of 2011 , $80 \%$ of teens use social networking sites, a dramatic increase over the $55 \%$ who did so just five years earlier. ${ }^{2}$ In 2010, an estimated twenty million minors used Facebook, ${ }^{3}$ and approximately $44 \%$ do so weekly. ${ }^{4}$ Even when teens do not directly pay for services, such as social networks and chat rooms, the providers of these programs depend on their presence in droves to persuade advertisers to pay for space. ${ }^{5}$ This burst of economic leverage

Edwin M. Thomas Professor of Law, J. Reuben Clark Law School, Brigham Young University. We gratefully thank Timothy West, Eli McCann, and the BYU Law Library Reference staff who assisted with research and editing, as well as many colleagues who offered substantive suggestions. We dedicate this paper to the delightful, brilliant, energetic, and thoughtful people who are the future of our economy, country, and world and who are now under age eighteen.

** J.D., J. Reuben Clark Law School, Brigham Young University.

1. Teen Market to Surpass $\$ 200$ Billion by 2011, Despite Population Decline, MARKETING CHARTS (June 28, 2007), http://www.marketingcharts.com/interactive/teen-market-to-surpass-200billion-by-2011-despite-population-decline-817; see also Cheryl B. Preston, CyberInfants, 39 PEPP. L. REV. 225, 267-70 (2012) (discussing minors' importance in the marketplace).

2. Amanda Lenhart et al., Pew Internet, Teens, Kindness and Cruelty on Social NETWORK Sites: HOW AMERICAN TEENS NAVIGATE THE NEW WORLd OF "DigitAl CitizenSHIP" 16 (Nov. 9, 2011), http://www.pewinternet.org/ /media//Files/Reports/2011/PIP_Teens_Kindness_ Cruelty_SNS_Report_Nov_2011_FINAL_110711.pdf.

3. Online Exposure, CONSUMER REPORTS, June 2011, at 30.

4. Koby Oppenheimer, Social Networking Sites: Growing Use Among Tweens and Teens, but a Growing Threat As Well?, TRENDS \& TUDES, Apr. 2008, at 1, http://harrisinteractive.com/news/ newsletters/K12news/HI_TrendsTudes_2008_v07_i03.pdf.

5. See Gwenn Schurgin O'Keeffe, et al., The Impact of Social Media on Children, Adolescents, and Families, 127 PEDIATRICS 800, 802 (2011) (discussing the widespread use and impact of advertising on social media). 
will certainly foreground the contract infancy doctrine, which permits a person under age eighteen to void a contract, with a few exceptions.

The continued viability of the infancy doctrine has been the subject of recent dispute. In a dramatic move, the reporters of the Restatement (Third) of Restitution and Unjust Enrichment in 2011 selected a minority rule requiring minors to make restitution of benefits enjoyed under voided contracts, ${ }^{6}$ a rule that Professor Perillo suggests has very little or no support outside of New Hampshire. ${ }^{7}$ While the Restatement is just advisory and other language in the same section may be used by judges to avoid the harsh results of this rule, ${ }^{8}$ now is the time to explore the continuing viability of the infancy doctrine.

We have elaborated in detail elsewhere on the parameters of the infancy doctrine, its exceptions, and its defenses. ${ }^{9}$ The purpose of this Article is to compare the infancy doctrine in contract law to the treatment of minors in other areas of law. This comparison will help to determine if the law generally has abandoned the protective view of youth that animates the infancy doctrine. ${ }^{10}$ The Article begins with a brief overview of the infancy doctrine and moves to critiques, including claims that the doctrine is inconsistent with other areas of law; is arbitrary and inappropriately tied to a fixed day rather than individual maturity levels; is without special constitutional support; and is unfair to an adult who fails to heed the infancy doctrine's warning about making money off minors. The Article demonstrates that persons under age eighteen-or sometimes seventeen or twenty-one-are still treated differently than adults across disciplines, the general consensus being that the legal disabilities afforded minors are warranted to protect against vulnerabilities that most outgrow as they mature.

It is true that a smattering of laws attempt to balance particular competing interests within the principle of protecting youth. ${ }^{11}$ When

6. REstATEMENT (THIRD) OF RESTITUTION \& UnJUST ENRichMENT § 33 (2011). For a discussion of the majority approach to restitution for minors' voided contracts, see Cheryl B. Preston \& Brandon T. Crowther, Infancy Doctrine Inquiries, 52 SANTA ClARA L. REV. 47, $62-63$ (2012).

7. Joseph M. Perillo, Restitution in a Contractual Context and the Restatement (Third) of Restitution and Unjust Enrichment, 68 WASH. \& LEE L. REV. 1007, 1016-17 (2011); see also Joseph M. Perillo, Calamari \& Perillo on Contracts $\S 8.8$ (6th ed. 2009) (New Hampshire rule) [hereinafter CALAMARI \& PERILLO].

8. For further discussion of RESTATEMENT (THIRD) OF RESTITUTION \& UNJUST ENRICHMENT, see infra Part 0.

9. Preston \& Crowther, supra note 6, at 47-66.

10. See id. at 64-66 (citing and refuting some of the major sources of criticism of the infancy doctrine).

11. See infra Part II. 
viewed at the surface, some laws governing adolescent rights and responsibilities thus appear piecemeal and inconsistent. ${ }^{12}$ When examined more closely, however, each legal framework is internally consistent with the goal of protecting minors and preserving parental responsibility through minors' vulnerable years. Further, each seeming exception is based on particular concerns not shared in contract law.

A study of other laws and exceptions actually reinforces the underlying rationales for the contract infancy doctrine and shows it to be worth preserving. As we have discussed elsewhere, the infancy doctrine may need further tailoring to better balance the interests of minors against those of adults in some markets. ${ }^{13}$ But, the essential characteristics of the doctrine remain viable and should not be changed by judicial fiat without thoughtful, consensus legislative action. The Article concludes that minors today are still in need of protections, ${ }^{14}$ if not more so. ${ }^{15}$

Part II of this Article briefly reviews the present contours of the infancy doctrine and then discusses the proposed treatment of the infancy doctrine in the Restatement (Third) of Restitution and Unjust Enrichment. Part III first reviews various critiques of the infancy doctrine. It then addresses many of the most significant laws applicable to minors and views the internal structure of such laws in comparison with the protections afforded to minors under the contract infancy doctrine. Part IV examines the arbitrary nature of the date of legal adulthood, a characteristic common to laws governing minority in all fields. It considers the option for an individualized, case-by-case, determination of maturity. Part V examines constitutional principles for protecting minors. Part VI concludes that legislatures should be responsible for any potential changes to the current laws protecting minors-rather than the courts, even those relying on the Third Restatement.

12. Rhonda Gay Hartman, Adolescent Autonomy: Clarifying an Ageless Conundrum, 51 HASTINGS L.J. 1265, 1267 (2000).

13. Preston \& Crowther, supra note 6, at 78-79.

14. Major scientific research supporting the infancy doctrine is discussed in Cheryl B. Preston \& Brandon T. Crowther, Legal Osmosis: Brain Science and the Infancy Doctrine (forthcoming).

15. For example, minors are leaving their parents' homes at a later age than they did in previous decades. Jordan Stanger-Ross et al., Falling Far From the Tree: Transitions to Adulthood and the Social History of Twentieth-Century America, 34 Soc. SCI. HIST. 625, 627 (2010); see also Preston \& Crowther, supra note 14 (discussing social science evidence about minors postponing adulthood). 


\section{The RUle AND the Restatement (THIRD) OF RESTITUtion AND UNJUST ENRICHMENT}

\section{A. The Rule}

The infancy doctrine, which permits a person who enters a contract while under legal age to void the contract during infancy and a short time into adulthood, was established in the common law before the American Constitution. ${ }^{16}$ The doctrine is based on the recognition that "minors are generally more vulnerable to exploitation than adults and less capable of comprehending the nature of the legal obligations associated with a contract." ${ }^{\prime 17}$ The established exceptions and defenses account for the occasional difficulty in the doctrine's application and for those circumstances where applying the doctrine would be unjust.

The most common defense to the infancy doctrine is that the contract provided necessities for the minor, such as food, clothing, and medical care, when a parent or guardian will not or cannot provide them. ${ }^{18}$ Historically, an adult who successfully asserts this defense is entitled to retain the quantum meruit value of the consideration she received under the contract, rather than enforcement of the contract as written. ${ }^{19} \mathrm{~A}$ similar defense based on emancipation applies if the minor is married, in the military, or abandoned by parents. ${ }^{20}$ These defenses are justified by the welfare of the minor, not the impact on adult contracting parties. The law encourages adults to assist minors who must fend for themselves. ${ }^{21}$ This is a narrow exception to the doctrine's intended purpose, which is to discourage adults from imposing economic commitments on children and teens. $^{22}$

16. See 5 Richard A. LoRD, WiLliston on Contracts § 9:2 (4th ed. 2009) [hereinafter WiLliston]. See generally Melvin John Dugas, Comment, The Contractual Capacity of Minors: A Survey of the Prior Law and the New Articles, 62 Tul. L. REv. 745 (1988) (providing a detailed discussion of early developments of infancy protections in French and Roman law and how these principles became incorporated into Louisiana law).

17. Preston, supra note 1, at 232; see also City of N.Y. v. Stringfellow's of N.Y., Ltd., 684 N.Y.S.2d 544, 550-51 (N.Y. App. Div. 1999).

18. WiLLISTON, supra note 16, §§ 9:18-9:21.

19. Preston, supra note 1, at 232; see also WILLISTON, supra note 16, § 9:18; M.O. Regensteiner, Annotation, Right of Infant Who Repudiates Contract for Services to Recover Thereon or in Quantum Meruit, 35 A.L.R.2D 1302 § 2(a) (1954).

20. WILLISTON, supra note 16, § 9:4.

21. See id. (stating that parents attempting to relieve themselves from liability by emancipating the child is contrary to public policy).

22. 42 AM. JUR. 2D Infants $\S 39$ (2011). 
The "retains benefit" defense, another narrow exception, is focused on the economic loss of the contracting adult. ${ }^{23}$ In most jurisdictions, the adult can require the minor to return the tangible remnant of the item sold to the minor, as long as it is still in the minor's possession, as a condition of the adult's duty to return the payment made by the minor. ${ }^{24}$ The minor's obligation extends no further.

Another defense protects adults who determine that, in good faith on a reasonable investigation of the other party's evidence of age, they are dealing with an adult, although that belief is later proven wrong. ${ }^{25}$ Fraudulent misrepresentation of age is also a defense to the infancy doctrine in some states. ${ }^{26}$ In other states, the adult's option is to bring an action in tort for fraud. ${ }^{27}$ The duty of adults to investigate sufficiently a minor's representation of her age so as to reasonably rely in good faith on it $^{28}$ traces to the supposition that adults know that minors have incentive to lie about age to satisfy short-term interests. ${ }^{29}$

In rare and exceptional cases, courts have denied the benefit of the infancy doctrine to a minor who has demonstrated sufficient bad faith and intentional purpose to defraud. ${ }^{30}$ For instance, malicious destruction of the consideration or actions with no justification but spite or injury to adults qualify. ${ }^{31}$

Some courts are bent on creating context-specific defenses. Exceptions may be warranted to permit waivers as a condition for participation in children's recreational sports sponsored by volunteers, ${ }^{32}$ arbitration regarding necessary medical treatment, ${ }^{33}$ or employment

\footnotetext{
23. Preston, supra note 1 , at 232.

24. Id. at 232; Preston \& Crowther, supra note 6, at 62-63.

25. Preston, supra note 1 , at 233.

26. Infants, supra note 22, § 101; e.g., Nichols v. English, 154 S.E.2d 239, 240 (Ga. 1967).

27. Williston, supra note 16, § 9:22; see also Royal Fin. Co. v. Schaefer, 330 S.W.2d 129, 130 (Mo. Ct. App. 1959) (“[A]n infant who induces another to contract with him by misrepresenting that he is of age to the adult's resulting injury, is liable in tort.”).

28. A.D. Kaufman, Annotation, Infant's Misrepresentation as to His Age as Estopping Him from Disaffirming His Voidable Transaction, 29 A.L.R.3D $1270 \S 3$ (1970); see, e.g., KAN. STAT. ANN. § 38-103 (2010) ("No contract can be thus disaffirmed in cases where, on account of the minor's own misrepresentations as to his majority ... the other party had good reasons to believe the minor capable of contracting." (emphasis added)).

29. Preston, supra note 1, at 233.

30. Preston, supra note 1 , at 233 .

31. Id.; see, e.g., Rivera v. Reading Hous. Auth., 819 F. Supp. 1323, 1331-32 (E.D. Pa. 1993) ("[Infancy doctrine] is not to be employed as a vehicle whereby the minor is enabled to practice unconscionable business methods.” (quoting Pankas v. Bell, 198 A.2d 312, 315 (Pa. 1964))).

32. See, e.g., Zivich v. Mentor Soccer Club, Inc., 696 N.E.2d 201, 205 (Ohio 1998).

33. See, e.g., Doyle v. Giuliucci, 401 P.2d 1, 3 (Cal. 1965); Leong ex rel. Leong v. Kaiser
} 
agreements in states allowing minors to work without parental consent. ${ }^{34}$ However, these exceptions should be made by legislatures who weigh competing public interests, not randomly by courts. ${ }^{35}$

\section{B. The Restatement}

The continued viability of the infancy doctrine is threatened by the 2011 publication of the Restatement (Third) of Restitution and Unjust Enrichment. The change did not result from a reasoned reconsideration in the process of adopting a restatement of contracts, and it was flown under the radar of most contract professors and scholars. The change is not simply an elaboration of traditional restitution and unjust enrichment theories; it could be interpreted as an attempt to gut centuries of the infancy doctrine.

The Restatement has two sections that address minors' liability in restitution. Section 16 deals with when the minor is the transferor and section 33 addresses the minor as the recipient. ${ }^{36}$ Both of these sections apply to minors, but they were written broadly to also apply to mental incapacity and municipal corporations. ${ }^{37}$ In trying to unify the law of restitution for all forms of incapacity, the Restatement takes a position that does not reflect current law relating to minority. Because the two relevant Restatement sections share the same underlying policy and overarching changes, this Article focuses its criticism on section 33 for simplicity.

Section 33(1) of the Restatement provides that, when a minor disaffirms a contract, the other party to the contract has a claim for restitution against the minor, regardless of whether the contract involved a necessary. ${ }^{38}$ The point of the infancy doctrine is to protect minors from their own bad judgment and remove the incentives for adults to deal with

Found. Hosps., 788 P.2d 164, 169 (Haw. 1990).

34. See, e.g., Sheller ex rel. Sheller v. Frank’s Nursery \& Crafts, Inc., 957 F. Supp. 150, 153-

54 (N.D. Ill. 1997); Douglass v. Pfleuger Haw., Inc., 135 P.3d 129, 138 (Haw. 2006).

35. See infra Part 0.

36. RESTATEMENT (THIRD) OF RESTITUTION \& UNJUST ENRICHMENT §§ 16, 33 (2011).

37. Id. § $16 \mathrm{cmt}$. a.

38. The Restatement provides in $\S 33(1)$ :

A person who renders performance under an agreement that is unenforceable by reason of the other party's legal incapacity has a claim in restitution against the recipient as necessary to prevent unjust enrichment. There is no unjust enrichment if the claimant receives the counterperformance specified by the parties' unenforceable agreement.

Id. $\S 33(1)$; see also id. $\S 16(1)$ (providing for the same rule where the minor is the transferor rather than the recipient). 
minors without parental involvement. ${ }^{39}$ The purpose of the necessities exception is mercy for the minor who is abandoned to her own devices and must contract for survival. ${ }^{40}$ Thus, the necessities exception protects adults by allowing such a minor to contract for food, shelter, medical care, and even transportation to work. ${ }^{41}$ This rewriting of the law has gutted the infancy doctrine through the back door of a remedies restatement, without confronting it head on in a contracts restatement, and, more importantly, without the input of the state legislatures, which have enacted the infancy doctrine in every state.

In addition, the Restatement demands restitution even if the adult is fully aware that the contracting party is a minor. ${ }^{42}$ The only restriction in the Restatement is that the adult must deal "with the [minor] in good faith on reasonable terms." 43 While this prerequisite is certainly better than none, it burdens the minor seeking to avoid the transaction with the necessity of proving a lack of good faith or unreasonable terms. In addition, an adult may charge a reasonable price for a trivial luxury item of limited use that the minor doesn't need and cannot foresee the burdens of the payments. The infancy doctrine squarely addresses this problem that is swept under the carpet in the Restatement.

Secondly, the presumptions of the infancy doctrine assume that the minor is disadvantaged by having to conduct complicated factual inquiries and litigation. ${ }^{44}$ As a result, the infancy doctrine presents mostly bright-line rules that have a clear outcome. The Restatement undoes this by requiring evidence of reasonable terms and good faith on the part of the adult. While a reasonable price may be discernible from comparables and experts, ${ }^{45}$ a finding of good faith often boils down to the imputation of nuanced motives and dueling testimony. Litigation based on such nuances is extremely expensive. We predict that when all of the evidence is in, a jury will still have the same assumptions about the incompetency and lack of judgment of children and teens that motivated the adoption of the infancy doctrine in the first place. Thus,

\footnotetext{
39. Preston \& Crowther, supra note 6, at 50, 63.

40. Id. at 52 .

41. Id. at 53.

42. RESTATEMENT (THIRD) OF RESTITUTION \& UNJUST ENRICHMENT § 33 cmt. f.

43. Id. § 33(2).

44. See infra Part IV (discussing how repeat players are benefited-and minors disadvantaged - with case-by-case determinations and complicated factual inquiries).

45. See, e.g., MEMC Elec. Materials, Inc. v. BP Solar Int'l Inc., 9 A.3d 508, 530 (Md. Ct. Spec. App. 2010) (finding an expert witness competent to testify about the reasonable price for silicon powder in a breach of contract case).
} 
the Restatement suggests a change in law that takes away the certainty of administration, increases expense, and is likely to end in the same result on the law in those cases where litigation is pursued. The unfortunate and significant difference is that the threat of such litigation will likely intimidate a minor into succumbing to the adult's demands and foregoing the right to avoid the contract. The Restatement effectively reverses existing law by making the minor's right too complex and expensive to assert.

After appearing to create expansive liability for contracting minors, the drafters of the Restatement then seem to backpedal to soften this result, but they do so by adding even more litigation complexity and expense. Section 33(3) provides a general and somewhat puzzling caveat: "Notwithstanding the unjust enrichment of the recipient, restitution may be limited or denied if it would be inconsistent with the protection that the doctrine of incapacity is intended to afford in the circumstances of the case." ${ }^{, 4}$ Discerning the intent of the doctrine of incapacity is not difficult for one who reads the cases or summaries. This intent is to allow minors to avoid contracts unless the contract was for a necessity or fell into one of the other developed exceptions. ${ }^{47}$ Taken literally, this provision simply reinstates the protection of the infancy doctrine and the results that the facts of a case would reach under the existing infancy doctrine.

So what is the point of the Restatement's changes? The Restatement takes away the infancy doctrine's clear, easy-to-apply standards, developed over centuries, and gives a court-after the minor is forced into litigation-vague and unbounded discretion to do something to avoid a skewed result. The Restatement removes the clarity that allowed minors to make clear to adults that their chances of recovery are slim and therefore that an out-of-court settlement is wise.

In defending the changes, the official comment $\mathrm{c}$ to section 33 makes flawed assumptions about the infancy doctrine. While recognizing that all disability doctrines are intended as protection, the comment states that "a person who lacks the capacity to undertake a legally binding obligation is foreclosed from participating in transactions that may be advantageous or even vitally necessary." 48 This conclusion is simply false with respect to the infancy doctrine and in most other mental

\footnotetext{
46. RESTATEMENT (THIRD) OF RESTITUTION \& UNJUST ENRICHMENT § 33(3).

47. See Preston \& Crowther, supra note 6, at 50-51.

48. RESTATEMENT (THIRD) OF RESTITUTION \& UNJUST ENRICHMENT § $33 \mathrm{cmt}$. c.
} 
incapacity doctrines as well. In such doctrines, a contract is voidable at the election of the person with the disability; it is not void and the adult cannot disavow the contract. ${ }^{49}$ A minor may choose to retain any contract if it is advantageous.

In cases where it is necessary for a minor to contract without parental approval, let alone "vitally necessary," both the necessities and emancipation defenses to the infancy doctrine render the contract enforceable. $^{50}$ In other cases, parents have the right to be involved. A parent who approves a transaction can cosign or otherwise accept liability that will make advantageous contracts enforceable.

Comment c continues to opine: "Significant costs are imposed on the other party to the transaction, whenever a person who has dealt in good faith with an incapacitated counterparty is required to forfeit an otherwise valid legal entitlement." ${ }^{\text {51 }}$ An adult that makes a good faith effort to verify age will not suffer forfeiture under the infancy doctrine. The fraudulent misrepresentation of age is an established defense to the infancy doctrine. ${ }^{52}$ An adult who discovers the other party is a minor can either decide not to enter a contract or take that risk. The changes in the Restatement shift the costs to the incapacitated party, who is already disadvantaged in a transaction with a fully capable adult.

Finally, comment c concludes that liability should be determined case by case, weighing each point on a cost-benefit scale: "It follows that the contours of legal responsibility in these cases are determined, not by measuring 'capacity to contract' against some a priori standard, but by weighing at each point the value of the protection secured against the cost of securing it." ${ }^{23}$ The cost of such litigation based on vague balancing of values is not only an inefficient waste of judicial resources, it also virtually ensures that challenges to enforcement are never brought. Moreover, implicit in this fact-intensive weighing is an examination of the vulnerability and "maturity" of the particular minor, an endeavor the Supreme Court has expressly identified as systematically prejudicial to minors. ${ }^{54}$ Part IV addresses the reasons behind the choice to base

\footnotetext{
49. 7 Joseph M. Perillo ET Al., Corbin On Contract § 27.2 (Rev. ed. 1993).

50. See supra text accompanying notes $18-20$.

51. RESTATEMENT (THIRD) OF RESTITUTION \& UNJUST ENRICHMENT $\S 33 \mathrm{cmt}$. c.

52. Preston \& Crowther, supra note 6, at 59-62; see also supra text accompanying notes 26-

53. RESTATEMENT (THIRD) OF RESTITUTION \& UNJUST ENRICHMENT § $33 \mathrm{cmt}$. c.

54. Graham v. Florida, 130 S. Ct. 2011, 2032 (2010), discussed in Part IV infra.
} 28. 
infancy incapacity on a bright-line age and all of the legal consequences that entails. ${ }^{55}$

The Restatement clearly tries to create a theoretical framework to make a minor liable on the contract although the contract has been avoided, ${ }^{56}$ a convoluted way of simply removing the right to avoid in the first place. In doing so, the Restatement recognizes well-accepted exceptions, such as the doctrines of necessaries, the duty to return consideration still in the minor's possession, and others. ${ }^{57}$ However, the Restatement does not simply "adopt a broad rule of liability for benefits received," as it acknowledges. ${ }^{58}$ Rather, it knowingly elevates a minority rule that minors must account for depreciation of the consideration received - a rule so rare that it has avoided any sincere scrutiny to date. ${ }^{59}$

Only one contract commentator, Professor Joseph Perillo, has addressed the merits of the new Restatement's position on the infancy doctrine. Although Professor Perillo in two short paragraphs approves, arguing that minors "should be held to their bargains, other than their entry into credit transactions," 60 he acknowledges that the new Restatement position has very little support outside of New Hampshire. ${ }^{61}$

The purpose of restatements is to restate the existing law to simplify and clarify the case law, unless there is a compelling reason to modernize or make a global policy change. The founding committee of the American Law Institute "recommended that the first undertaking of the Institute should address uncertainty in the law through a restatement of basic legal subjects that would tell judges and lawyers what the law was. The formulation of such a restatement thus became ALI's first endeavor." ${ }^{62}$ If there is a reason to make a global policy change in the infancy doctrine, legislatures should do it, not courts.

Social judgments about the relative costs and benefits of the infancy doctrine have been established in its contours, exceptions, and defenses.

55. See infra Part IV.

56. See, e.g., RESTATEMENT (THIRD) OF RESTITUTION \& UNJUST ENRICHMENT § $33 \mathrm{cmt} . \mathrm{d}$ (discussing a minor's liability in restitution despite avoidance of liability in contract).

57. Id.

58. Id. § 33 reporter's notes, cmt. d.

59. Id. For more discussion on this minority rule, see Preston \& Crowther, supra note 6, at 6263. For a discussion of the majority approach to restitution for minors' voided contracts, see id. at $62-64$.

60. Perillo, supra note 7.

61. Id.; see also CALAMARI \& PERILLO, supra note 7.

62. ALI Overview, AM. L. INST., http://www.ali.org/index.cfm?fuseaction=about.institute projects (last visited Feb. 24, 2012). 
These have been reified in many state statutes. The Restatement's support for a minority rule is misplaced.

\section{TREATMENT OF MINORS ACROSS LEGAL DISCIPLINES}

One concern with the infancy doctrine is that it is outdated and has failed to keep up with developments in other areas of law affecting adolescents. Thus, retaining its protections is no longer warranted. In other words, do advancements in the way other areas of the law treat minors demonstrate that contract law is particularly anachronistic, as some commentators have suggested? This Part begins with a review of those critics who argue that the law's treatment of minors is hopelessly jumbled and without bedrock principles. Then we will survey a number of legal disciplines' conceptions and treatments of minors. This Part concludes that, upon close examination, the field of adolescent law reveals fundamental consistency and illustrates the principles that justify the continued application of the infancy doctrine. Undeniably, some areas of the law hold minors more or less responsible based on various rationales promoting policy justifications specific to the law in those areas. It is crucial to identify, in each of these cases, which policy considerations support courts' decisions to hold minors more accountable in these few instances and how the principles remain fundamentally consistent.

The Supreme Court has recognized that "[c]hildren have a very special place in life which law should reflect." 63 United States law does reflect this "special place," as seen by the numerous carve-outs and individual rules in most of the major areas of law. Some recent commentators assert that these laws are inconsistent, do not reflect our understanding about minors, or otherwise warrant abandonment of the infancy doctrine. For example, Professor Juanda Daniel criticizes the infancy doctrine by arguing:

[O]ther areas of American law recognize that minors are capable of understanding and appreciating their legal actions and thus afford minors more autonomy in their affairs. However, even when a minor is deemed competent to make decisions in one area of the law, he may

63. Bellotti v. Baird, 443 U.S. 622, 633 (1979) (plurality opinion) (quoting May v. Anderson, 345 U.S. 528, 536 (1953) (Frankfurter, J., concurring)). 
still be deemed incompetent to make decisions regarding his closely connected contractual affairs. ${ }^{64}$

Professor Daniel discusses tort law, criminal law, and consent law as specific examples, ${ }^{65}$ all of which are discussed below. Although we disagree with Professor Daniel that other areas of law are inconsistent with the infancy doctrine, she correctly recognizes that, superficially, these many areas of law may appear inconsistent.

Professor Rhonda Hartman also finds inconsistency in these laws. She states that "social norms that are closely allied with governing law treat adolescents as though they are decisionally capable, producing a kaleidoscope approach to adolescent rights with endless variegated exceptions and circuitous results." 66 She specifically cites consent to medical treatment as an area where "[t]he rules that result from presumptive decisional incapacity 'meander like a restless wind inside a letter box, tumbling blindly' as they inadequately address adolescent issues." 67

This line of criticism is not new. The infancy doctrine has frequently been criticized as being inconsistent with other areas of the law. For example, in 1965, the Supreme Court of New Hampshire stated that "[a] stranger must think it strange that a minor in certain cases may be liable for his torts and responsible for his crimes and yet is not bound by his contracts."68 Similarly, in the 1980s, Professor Wadlington wrote that "[a]s a result of this somewhat haphazard process, the rules regarding majority today are a melange of legal anachronism and contemporary expediency which reflect only minimally our current understanding about the intellectual and emotional capacities and interests of young persons." 69

Notwithstanding these critiques, when other areas of the law are put into context and viewed in light of competing policies, they are fully consistent with the goal of protecting minors. Even the seeming exceptions to the rules of "presumptive decisional incapacity" recognize that minors are vulnerable and are the exceptions are justified by minors'

64. Juanda Lowder Daniel, Virtually Mature: Examining the Policy of Minors' Incapacity to Contract Through the Cyberscope, 43 GoNZ. L. REV. 239, 261 (2008).

65. Id. at 262-67.

66. Hartman, supra note 12, at 1267 .

67. Id. (quoting THE BEATLES, ACROSS THE UNIVERSE (EMI Blackwood Music Inc. 1968)).

68. Porter v. Wilson, 209 A.2d 730, 731 (N.H. 1965).

69. Walter J. Wadlington, Consent to Medical Care for Minors: The Legal Framework, in CHILDREN’s COMPETENCE TO CONSENT 57, 57 (Gerald P. Koocher et al. eds., 1983). 
best interests. Rather than undermine the infancy doctrine, a comparison of the major areas of law reinforces it.

\section{A. Tort Law}

Under tort law, minors have always been held liable for their intentional torts, ${ }^{70}$ and most jurisdictions hold at least some minors liable for mere negligence. ${ }^{71}$ However, most jurisdictions temper this rule by deeming very young minors incapable of negligence based on their limited capacities, especially for children under seven years old, ${ }^{72}$ or by courts taking into account the limited capacities in deciding how a "reasonable minor" with similar age and capabilities should act. ${ }^{73}$

It does not implicate the infancy doctrine to permit the punishment of minors for acts, which, similar to crimes, are a knowing violation of malum in se social norms that the law has incorporated as intentional torts. $^{74}$ Intentional torts are the kinds of conduct that require very little judgment to recognize as unacceptable in society. In this case, society has determined that the value of holding minors who act with intent accountable for their harmful actions outweighs the protections that they may deserve in other contexts, because minors must be taught what is allowed and what is not. But this slice of liability is narrow and different in kind than the infancy doctrine. These rules are unrelated to protecting minors from injury to themselves. Rather they are post hoc punishment directed at consequences for injuries a minor has caused to others who did not choose to deal knowingly with a minor for financial gain. Criminal law strikes a similar balance, as addressed below. ${ }^{75}$

Even with respect to mere negligence, tort doctrine is clearly distinguishable from contract doctrine, both in practical application and in policy. First, tort victims do not choose who commits a tort against them. They become victims of whatever tortfeasor comes along,

70. See, e.g., Victor E. SCHWARTZ ET AL., Prosser, WADE AND SCHWARTZ's TORTS 17 (12th ed. 2010) (illustrating minors' ability to form the requisite intent for an intentional tort using Garratt v. Dailey, 279 P.2d 1091 (Wash. 1955)).

71. RESTATEMENT (SECOND) OF TORTS § 283A (1979).

72. Id. $\S 283 \mathrm{~A} \mathrm{cmt.} \mathrm{b.} \mathrm{For} \mathrm{a} \mathrm{list} \mathrm{of} \mathrm{jurisdictions} \mathrm{that} \mathrm{cut} \mathrm{off} \mathrm{liability} \mathrm{for} \mathrm{young} \mathrm{minors,} \mathrm{see} \mathrm{the}$ cases in the reporter's notes for section 283A.

73. Id. § 283A.

74. See Dawson v. Contractors Transp. Corp., 467 F.2d 727, 729 \& n.1 (D.C. Cir. 1972) (explaining that tortfeasors may recover a portion of a settlement from joint tortfeasors where "the tort is not intentional or malum in se.”).

75. See infra Part III.B. 
notwithstanding their efforts to avoid dangerous situations and people. A person cannot avoid falling victim to a tort committed by a minor, unless by never venturing out of an adult-only community. On the other hand, contracting parties always have the ability to choose with whom they contract and can choose to contract only after taking reasonable measures to assure that the other party is an adult with legal capacity to be bound. Thus, tort liability for the conduct of minors against innocent victims does not conflict with the contract infancy doctrine. In contract law, an adult can easily avoid the consequences by not contracting with minors.

Second, parents are ultimately liable for the consequences of a tort committed by a minor. ${ }^{76}$ Tort law puts the onus on adults to teach their children to adhere to basic social decencies or to exercise sufficient control over their children to stop them from harming others. ${ }^{77}$ Thus, the deterrent effect of tort law is to motivate parents to control or teach their children before unleashing them on society. ${ }^{78}$ Moreover, legal enforcement of a tort judgment is ultimately against the parent. ${ }^{79}$ The purposes of tort law-to deter wrongful conduct and compensate the injured party ${ }^{80}$ - focus ultimately on adults as responsible agents, not on any assumption that minors are responsible agents.

Third, tort law is not formulated intentionally to discourage adult interaction with minors. One of the express purposes of the infancy doctrine is to warn adults to stay away from minors when entering financial transactions. ${ }^{81}$ Contract law, as with all areas of law, aims at the behavior of adults, with the intent to stop adults from taking advantage of the vulnerabilities of youth. ${ }^{82}$ Similarly, tort law aims at stopping adults from allowing untrained children to wreak havoc on neighbors. Contract law assumes exchanges of consideration that have an economic contour, even if not always set forth in terms of cash. ${ }^{83}$ The

76. Randall K. Hanson, Parental Liability for Torts of Children: Balancing the Rights of Victims and Parents, 9 MiDWEST L. REV. 77, 79 (1990) ("All states have passed modern tort statutes imposing varying degrees of responsibility on parents for the wrongful actions of their children.”).

77. Id. at 79-80, 84 (stating that increases in parental liability ceilings "indicate a trend toward imposing greater parental responsibility for juvenile misconduct," and that such increases "would encourage parents to exercise greater influence over their children's activities").

78. Id. at 79 .

79. See id. at 78-79 (noting that most minors are insolvent).

80. RESTATEMENT (SECOND) OF TORTS § 901 (1979); see also Schickling v. Aspinall, 369 S.E.2d 172, 174 (Va. 1988); Borish v. Russell, 230 P.3d 646, 650 (Wash. Ct. App. 2010).

81. See 43 C.J.S. Infants § 210 (2010).

82. See id.

83. RESTATEMENT (SECOND) OF CONTRACTS § 71 (1981). 
law wants adults to conduct such exchanges only with other adults, as greed could cause adults to lure children into improvident transactions. ${ }^{84}$ The adult has a safe option in conducting the transaction with the child's parent or guardian instead. Society squarely discourages adults from being physically near to or otherwise interacting with children without parents around to avoid exploitation of children for other purposes, such as in online chat rooms, adult businesses, and restraints on the movement of sexual predators. ${ }^{85}$

An adult acting with reasonable care can avoid entering contracts with minors in all cases except ones where the minor affirmatively misrepresents his age and the adult, after reasonable inquiry and investigation, has no reason to suspect the deception. The infancy doctrine makes an exception to protect adults in such cases. ${ }^{86}$ Adults who contract with minors put themselves in a situation that could have been avoided altogether, unlike victims of torts. The infancy doctrine is entirely consistent with the purpose of contract law, which is "to enforce the reasonable expectations of parties induced by promises," adults are expected to know that transactions with minors may be voidable by the minor.

\section{B. Criminal Law}

Similar policy reasons exist to explain supposed inconsistencies in criminal law. ${ }^{88}$ Recent changes in the treatment of minors in criminal law are highly consistent with the policies and aims of contract law and show a marked movement toward greater protection of minors and taking into account their cognitive limitations. ${ }^{89}$

The value of protecting perpetrators of crime carries obvious weight when it comes to minors. The juvenile justice system focuses on

84. See 43 C.J.S. Infants $\S 210$ (2010).

85. See, e.g., Sex Offender Registration \& Notification Act, 42 U.S.C. § 16913 (2006) (requiring sex offenders to register and keep current an address in the jurisdiction where the offender resides), invalidated by United States v. Nasci, 632 F. Supp. 2d 194 (N.D.N.Y. 2009).

86. Preston \& Crowther, supra note 6, at 59-62.

87. 6 JOHN E. MurRAY, JR. \& TIMOTHY MURRAY, CORBIN ON CONTRACTS $§ 570$ (Interim ed. Supp. 2009).

88. See Daniel, supra note 64, at 263-67.

89. See, e.g., Graham v. Florida, 130 S. Ct. 2011, 2034 (2010) (holding that nonhomicide juvenile offenders cannot be sentenced to life imprisonment without parole); Roper v. Simmons, 543 U.S. 551, 575 (2005) (holding that juvenile offenders cannot receive the death penalty). 
rehabilitation over other penological justifications. ${ }^{90}$ This reasoning is tied to studies that show antisocial, or criminal, tendencies in most youths are often fleeting and are usually outgrown. ${ }^{91}$ It is simply too difficult to distinguish those individuals whose criminal natures are "permanent" from those who will naturally reform once they mature. Supreme Court precedent reflects this rationale, ${ }^{92}$ recognizing that minors are not formed and fixed and that their fluidity is a source of vast vulnerability, the kind of vulnerability protected by the infancy doctrine.

Indeed, criminal law in some extreme cases blurs the cutoff between minors and adults, allowing transfer of older adolescents to adult court when they have committed a serious and, typically, violent offense. ${ }^{93}$ Treating some minors as adults in this situation does not undermine the incapacity rationales of the infancy doctrine; at best, it may be precedent for finding a way to classify a few minors as unlike the majority under the rule if some outrageous conduct is involved. In the case of serious crime, society's desire for crime control and effective law enforcement may take precedence over the arguments of immaturity, which still play a role in deciding whether such treatment is appropriate; ${ }^{94}$ but, the transfer to adult court of certain minors does not erase other protections now in place for minors. In addition, as one commentator has noted, "a plausible argument could be made that the decision to make a contract is more difficult and requires greater capacity than resisting a compulsion to kill someone." 95

With respect to the more significant issues in criminal law, the trend has been to increase protections based on our conception of the abilities of individuals under age eighteen. With respect to capital punishment, in Roper v. Simmons, the Supreme Court detailed an evolution toward even stricter adherence to the notion that children under the age of eighteen must be treated differently than adults. ${ }^{96}$ The Court held that the Constitution barred capital punishment against minors. ${ }^{97}$ Sixteen years earlier in Stanford $v$. Kentucky, the Court approved a state statute that

\footnotetext{
90. Elizabeth S. Scott, The Legal Construction of Adolescence, 29 HofSTRA L. REV. 547, 578 (2000).

91. Id. at 587.

92. Graham, 130 S. Ct. 2011; Roper, 543 U.S. 551.

93. Larry Cunningham, A Question of Capacity: Towards a Comprehensive and Consistent Vision of Children and Their Status Under Law, 10 U.C. DAVIS J. JuV. L. \& POL’Y 275, 345 (2006).

94. Id. at 344, 347-48.

95. Id. at 350 .

96. 543 U.S. 551, 561-64 (2005).

97. Id. at 575
} 
allowed the execution of offenders over age fifteen but under age eighteen, thus recognizing something like a "mature" minor exception. ${ }^{98}$ However, the Roper Court, armed with greater knowledge about the developing mind, overruled Stanford, supporting a consistent trend toward abolishing the death penalty for juveniles between ages sixteen and eighteen. " "[T]he consistency in the trend toward abolition of the practice-provide[s] sufficient evidence that today our society views juveniles, in the words Atkins used respecting the mentally retarded, as "categorically less culpable than the average criminal.",100 In addition, the Court "acknowledge[d] the overwhelming weight of international opinion against the juvenile death penalty, resting in large part on the understanding that the instability and emotional imbalance of young people may often be a factor in the crime."

Since Roper, the Supreme Court has continued this trend in Graham $v$. Florida, where it held that juvenile nonhomicide offenders could not be sentenced to life imprisonment without parole. ${ }^{102}$ The Court reasoned that "[i]t remains true that '[f]rom a moral standpoint it would be misguided to equate the failings of a minor with those of an adult, for a greater possibility exists that a minor's character deficiencies will be reformed." 103 Such reasoning is entirely consistent with the infancy doctrine, which recognizes that minors lack capacity and develop maturity and character over time.

\section{Healthcare Law}

\section{Consent to Treatment}

Minors generally may not consent to their own medical treatment. ${ }^{104}$ Instead, their parents or guardians have legal responsibility for making the complex decisions related to medical care. As with the contract infancy doctrine, the parental consent theory seeks to protect minors

\footnotetext{
98. 492 U.S. 361, 380 (1989), overruled in part by Roper v. Simmons, 543 U.S. 551 (2005).

99. Roper, 543 U.S. at 566-67.

100. Id. at 567 (quoting Atkins v. Virginia, 536 U.S. 304, 316 (2002)).

101. Id. at 578 .

102. 130 S. Ct. 2011, 2034 (2010).

103. Id. at 2026-27 (second alteration in original) (quoting Roper, 543 U.S. at 570).

104. Scott, supra note 90, at 566 (citing Susan D. Hawkins, Note, Protecting the Rights and Interests of Competent Minors in Litigated Medical Treatment Disputes, 64 FoRdHAM L. REV. 2075, 2075 (1996); Lois A. Weithorn \& Susan B. Campbell, The Competency of Children and Adolescents to Make Informed Treatment Decisions, 53 CHILD DEV. 1589, 1589 (1982)).
} 
from poor decisions that may have lasting physical and mental impact. There are, however, some situations where minors are not required to have parental consent. An analysis of these exceptions illustrates why none of them tarnishes the fundamental principles underlying the infancy doctrine. Further, even when an exception applies, doctor ethics, hospital policies, and some states still require providers "to determine and document that the services are clinically indicated for the minor's well-being," effectually affirming the principle that limits minors' abilities to decide for themselves. ${ }^{105}$

Orthodontic braces, aesthetic surgery, and other limited-pain nonessential treatments are the closest comparisons to the kind of things a minor would choose to obtain in the same way a minor chooses to enter into a contract for a motorcycle or a computer game. In such instances minors might want some cosmetic treatment based on a friend's opinions, or their own self-conscious insecurities, or with the encouragement of a physician looking to take advantage of the minor's poor decision-making.

Medical emergencies are generally an exception to this rule requiring parental consent, and services provided to minors without parental consent in emergency situations are rarely challenged. ${ }^{106}$ This relaxation of the ordinary requirement "facilitates necessary treatment when parental consent may be hard to get, under circumstances in which it is assumed that parents would likely consent."107 For example, adolescents may go rock climbing or jet-skiing under circumstances where their parents are not with them and cannot be contacted quickly. In such cases, providing medical services may directly be a way of mitigating the youth's reckless or poor decisions. The exception to parental consent in emergency medical treatments seeks to relieve minors from harm in situations where a parent or guardian cannot be found; the exception is obviously protection oriented. It permits healthcare providers to react in

105. Rhonda Gay Hartman, Coming of Age: Devising Legislation for Adolescent Medical Decision-Making, 28 AM. J.L. \& MED. 409, 420 (2002).

106. Scott, supra note 900, at 567 \& n.79 (citing Angela R. Holder, Minor's Rights to Consent to Medical Care, 257 JAMA 3400, 3400 (1987)) (arguing that there have been very few cases in which a physician has been sued for non-negligent care of an adolescent without parental consent); see also Committee on Pediatric Emergency Medicine, Consent for Emergency Medical Services for Children and Adolescents, 111 PEDIATRICS 703, 703 (2003) (“[E]very state has enacted minor consent statutes addressing some or all of these exceptions to the 'general rule' [of requiring parental consent].”).

107. Scott, supra note 90, at 567. 
an emergency. ${ }^{108}$ It is difficult to conceive of an "emergency" where minors must enter a contract before their parents can be located, except for contracts where minors are emancipated and, without the care and support of parents, must fend for themselves. The infancy doctrine has an exception for such cases, as well. ${ }^{109}$

Even when immediately and presently suffering the consequences, minors sometimes defy their own best interests. Adolescents are frequently exposed to drugs, alcohol, sexual diseases, and other dangers to their health. The law tries to protect minors from their own "bad decisions that could adversely impact their health." 110 Legislatures have determined there would be an unacceptable risk to minors if parental consent was required for minors to get medical help for these problems. ${ }^{111}$ Teenagers might conceal their addiction or condition, rather than obtain needed treatment or counsel, out of fear for their parents' reactions, ${ }^{112}$ or because they live in an abusive home. ${ }^{113}$ Moreover, society has an interest in reducing the incidences of these problems in the teen population, ${ }^{114}$ especially with respect to communicable diseases. Making an exception to deal with particular kinds of problems in certain cases after the teen has exercised bad judgment is not inconsistent with the infancy doctrine's focus on discouraging adults from inducing teens into financial transactions.

In healthcare law, some courts have recognized a "mature minor" doctrine, which is an ad hoc equivalent of the emancipated minor exception in the contract law infancy doctrine. It has gained some recognition as an acceptable judicial bypass to broader parental consent requirements. ${ }^{115}$ The Supreme Court explains the doctrine as applying in

\footnotetext{
108. Id.

109. Preston \& Crowther, supra note 6, at 52-57.

110. Cunningham, supra note 93, at 317.

111. See, e.g., CAL. FAM. CODE § 6929(b) (West 2012) (providing that parental consent is needed in cases of a minor seeking treatment for drug and alcohol related problems); VT. STAT. ANN. TIT. 18, § 4226 (West 2012) (providing that if a minor has or is suspected of having drug or alcohol related issues or a sexually transmitted disease, parental consent is not necessary).

112. Scott, supra note 90 , at 568 .

113. Id.; see also Hartman, supra note 12, at 1309-10.

114. Scott, supra note 90, at 568.

115. Eight states statutorily allow minors to try for the mature minor exception to parental or physician decision-making. NATIONAL SURVEY OF STATE LAWS 341-71 (Richard A. Leiter ed., 6th ed. 2008). Many other courts seem to grant similar case-by-case exceptions, although without the same label.
} 
instances where a court has made a determination that a particular minor "is mature and capable of giving informed consent."

Because adolescence is a transition stage from childhood to adulthood, ${ }^{117}$ it may seem that the mature minor adjudication in medical consent law indicates the minor has adult-like decisional capacity. In application, however, the interpretation of "mature" and "capable" is usually based on whether the minor's desires appear to be mature and capable in the circumstances, not whether the minor individually is sufficiently mature to be capable of broad decision-making ability. The doctrine is, in practice, more like deciding the specific medical procedure is in the minor's best interests, rather than that the minor is mature enough to consent to a specific medical procedure. ${ }^{118}$ In addition, the determination of whether or not a minor is mature is based on the minor's capacity for factual understanding rather than her reasoning capabilities. ${ }^{119}$ Thus, the mature minor standard does not support the argument that older minors be stripped of the protections of the infancy doctrine.

These judicial bypasses to ordinary parental consent requirements, such as emergency treatment or mature minor standards, are not always in response to a request by a minor. Physicians can also use bestinterests decisions to overcome parental consent or lack of consent and, in some cases, to force treatment on an unwilling minor. For instance, Thomas, a fifteen-year-old boy, was diagnosed with a mediastinal tumor. ${ }^{120}$ His biological father died from a lung cancer tumor just a few months before. To save Thomas, his doctors determined that diagnostic surgery was needed immediately. ${ }^{121}$ Thomas refused because of "his 'strong phobia for needles."”122 Unsurprisingly, the family court granted

116. Planned Parenthood of Se. Pa. v. Casey, 505 U.S. 833, 899 (1992).

117. See C. Antoinette Clarke, The Baby and the Bathwater: Adolescent Offending and Punitive Juvenile Justice Reform, 53 U. KAN. L. ReV. 659, 691-92 (2005); Terry A. Maroney, The False Promise of Adolescent Brain Science in Juvenile Justice, 85 Notre DAME L. REV. 89, 97 (2009).

118. See, e.g., Planned Parenthood of S. Ariz. v. LaWall, 189 F. Supp. 2d 975, 981-82 (D. Ariz. 2001) (reasoning that the Arizona statute directs a judge to begin with the maturity assessment, then use a best-interests approach if she finds the minor not mature, though finding a minor not mature is itself an assessment of best interests).

119. Daniel, supra note 64, at 266; see also Scott, supra note 90, at 568 ("No one argues that minors should be deemed adults because they are particularly mature in making decisions in these treatment contexts.").

120. In re Thomas B., 574 N.Y.S.2d 659, 660 (N.Y. Fam. Ct. 1991).

121. Id.

122. Id. 
the state the power to proceed with the surgery over Thomas's protests. $^{123}$

The mature minor doctrine is not tied to a sense that children are sufficiently mature as they near age eighteen and should have more deference. One case involved a young man "just weeks shy of his 18th birthday." " He was diagnosed with cancer and told that blood transfusions would be necessary to offset the effects of chemotherapy. ${ }^{125}$ Based on religious beliefs, he and his parents refused the blood transfusions. ${ }^{126}$ Though some minors have been adjudicated mature in similar circumstances, ${ }^{127}$ this young man was not. ${ }^{128}$ The court determined that "his refusal to consent to blood transfusions is not based upon a mature understanding of his own religious beliefs or of the fatal consequences to himself." 129 This finding came just after the court stated that this was an "intelligent, articulate young man."130

In another case, the Illinois Supreme Court declared that a person very nearly eighteen may well be adjudged to be mature by the trial court if she "is mature enough to appreciate the consequences of her actions, and [she] is mature enough to exercise the judgment of an adult." ${ }^{\text {,131 }}$ In the end the determination of whether the minor understands the consequences seems to turn on whether the minor is making a choice that satisfies their adult judge's sense of what is in the minor's best interests.

The development of the mature minor doctrine is not a recognition of changing trends in maturation suggesting that the age of consent should be lowered. Rather, it is a vehicle whereby a court can override parental consent statutes and decisions made by minors because the judge or medical personnel determines that a treatment is in the child's best interests. It is not used to force minors to live with the consequences of bad decisions and thus has no parallel to the infancy doctrine.

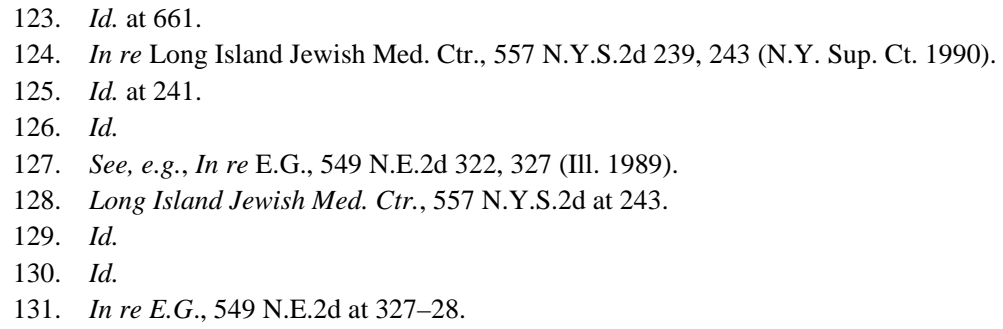


[Vol. 61

\section{Consent to Abortion}

Prior to Planned Parenthood v. Danforth, ${ }^{132}$ almost every state required parental consent for medical procedures, even abortions. In Danforth, the Supreme Court held that always requiring parental consent for minors to have abortions was unconstitutional unless there is some form of judicial bypass available, slight as it may be. ${ }^{133}$ Most states have responded by inserting exceptions similar to those for basic medical treatment, ${ }^{134}$ thereby satisfying the Supreme Court's requirement of alternatives to protect a child's possible best interests in varying circumstances. This allows the minor to choose to have an abortion if another adult, in most states a judge, ${ }^{135}$ decides that it is either in the minor's best interests or that the minor has sufficient "maturity" to make the decision herself, ${ }^{136}$ which in practice still translates into what the judge believes is in the minor's best interests.

Only Connecticut statutorily allows minors to consent to their own abortions without some parental notice or consent, or judicial oversight. ${ }^{137}$ Even then, adult involvement is required at some point. Connecticut requires a physician to give information to the minor and "[d]iscuss the possibility of involving the minor's parents, guardian or other adult family members in the minor's decision-making concerning the pregnancy and whether the minor believes that involvement would be

\footnotetext{
132. 428 U.S. 52 (1976).

133. Id. at 74; see also Planned Parenthood of Se. Pa. v. Casey, 505 U.S. 833, 900-01 (1992) (upholding Pennsylvania statute containing one-parent consent requirement with a judicial bypass option); Ohio v. Akron Ctr. for Reprod. Health, 497 U.S. 502, 520 (1990) (holding that judicial bypass provision was sufficient even though minor was required to meet a heightened standard of proof to evince her best interests or personal maturity); Planned Parenthood Ass'n of Kan. City, Mo., Inc. v. Ashcroft, 462 U.S. 476, 494 (1982) (upholding Missouri statute requiring parental or juvenile court consent for an abortion).

134. NATIONAL SURVEY OF STATE LAWS, supra note 115, at 341-71.

135. In Maryland, the attending physician may make a judgment concerning a minor's best interests and waive the requirement for parental notice. MD. CODE ANN., HEALTH-GEN. § 20-103(c) (West 2009).

136. Bellotti v. Baird, 443 U.S. 622, 643-44 (1979).

137. Conn. Gen. StAT. AnN. § 19a-601 (2011) (providing that minors must receive counseling prior to receiving an abortion, and discussing whether the minor's parents should be involved); see also NATIONAL SURVEY OF STATE LAWS, supra note 115, at 341-71 (summarizing state abortion laws); Tracy Truly, TeEn Rights 261-321 (1st ed. 2002) (same). Florida law has vacillated as the courts and legislature have fought it out, but currently, the law requires parental notification or judicial bypass. FLA. STAT. ANN. § 390.01114 (2011) (enacted by a constitutional amendment).
} 
in the minor's best interests." 138 The decision is then left to the minor after the mandated counseling. ${ }^{139}$

The Supreme Court's explanation for requiring these exceptions to parental consent is not based on a holding that minors are fully capable of making complex decisions, but rather that the law needs to protect the best interests of children. The Court reasons that sometimes leaving the decision with parents may result in harm to the minor. ${ }^{140}$ As with drug abuse, sexually transmitted diseases, and pregnancy generally, some minors considering having an abortion may have legitimate reasons to fear their parents' response, primarily because of abusive circumstances at home. ${ }^{141}$ Where parents' interests do not align with a pregnant minor's best interests, such as when parents might be more concerned about themselves and their reputation in the community than the longterm consequences to their minor child, the state may determine it must step in to protect the welfare of the child. ${ }^{142}$ The state does not simply grant the minor decision-making authority without supervision.

In Bellotti v. Baird, the Court addressed specifically a pregnant minor's vulnerability. ${ }^{143}$ The Court recognized that an unmarried pregnant minor was in an especially vulnerable situation "considering her probable education, employment skills, financial resources, and emotional maturity," 144 and that "a girl of tender years, under emotional stress, may be ill-equipped to make [the decision for an abortion] without mature advice and emotional support." ${ }^{\text {"145 }}$ Ultimately, the framework established by the Supreme Court exists to protect minors rather than to give them more autonomy in making important decisions. When speaking of a minor's "rights" under the exceptions, the Court focuses on a minor's right to be free from further abuse that may result from parental involvement and places the state in the parental role.

\footnotetext{
138. Conn. Gen. StAT. AnN. § 19a-601(a)(5).

139. Id. § 19a-601(b).

140. Planned Parenthood of Se. Pa. v. Casey, 505 U.S. 833, 899 (1992).

141. Hodgson v. Minnesota, 497 U.S. 417, 438-39 (1990).

142. See Bellotti v. Baird, 443 U.S. 622, 647 (1979) (“[M]any parents hold strong views on the subject of abortion, and young pregnant minors, especially those living at home, are particularly vulnerable to their parents' efforts to obstruct both an abortion and their access to court." (emphasis added)).

143. Id. at 634, 639 (stating that the background for the constitutional issue was "the peculiar vulnerability of children; their inability to make critical decisions in an informed, mature manner; and the importance of the parental role in child rearing”).

144. Id. at 642 .

145. Id. at 641
} 
Once a minor is pregnant, the state's interest in protecting her from some serious choices she probably does not understand and cannot fully calculate, and from vulnerability to the influences of others especially adults, is in many respects too late. An acknowledgement of the forces in society that leave pregnant teens unable to care for and raise a child in a stable environment is a recognition of their vulnerability and not inconsistent with the infancy doctrine in contracts. If a teen is married, in military service, or otherwise living as an adult away from parents, the exceptions for emancipation and necessaries under the infancy doctrine applies. $^{146}$

\section{Family Law and Custody Disputes}

In family law, many states permit older minors to have input in resolving custody disputes. ${ }^{147}$ This "input" should not be confused with an ultimate right to decide, which still rests with the judge. ${ }^{148}$ In each child custody dispute, the state functions as parens patriae, acting as the child's parent to determine what is in the child's best interest. ${ }^{149}$ In the family law setting, courts may take an individualized approach, focusing on the individual maturity of the child rather than setting a bright-line cutoff for the ability to be involved in choosing custodial arrangements. ${ }^{150}$ At first sight, it may seem that courts deem some children mature enough to contribute to critical life decisions in family law, while at the same time, treating them as insufficiently mature to enter into basic contracts, but a closer look belies this.

Trial courts have wide discretion when awarding child custody, and many have recognized that the child's wishes are a factor to consider, where appropriate. ${ }^{151}$ Before accounting for the child's wishes, a court will judge the maturity of the minor based on the individual minor's "age, intelligence, and discretion to exercise an enlightened judgment . . .

\footnotetext{
146. Preston \& Crowther, supra note 6, at 55.

147. D.W. O'Neill, Annotation, Child's Wishes as Factor in Awarding Custody, 4 A.L.R.3D $1396 \S 3(1965)$.

148. Id. §§ 1(a), 2(a).

149. 43 C.J.S. Infants $\S 4$ (2004).

150. O’Neill, supra note 147, § 9 .

151. See, e.g., In re Marriage of Andersen, 603 N.E.2d 70, 73 (Ill. App. Ct. 1992) ("The trial court should give considerable weight to a mature child's custodial preference when it is based on sound reasoning.”); Pekarek v. Pekarek, 384 N.W.2d 493, 498 (Minn. Ct. App. 1986) (holding that, although the children were sufficiently mature, the trial court did not err in not asking for the children's preferences because they were in a "confused and anxious state").
} 
as to [her] future welfare." ${ }^{152}$ However, even where courts account for the wishes of the child, those wishes are ultimately subordinated to what the judge deems the "best interests of the child," which may not align with that child's wishes. ${ }^{153}$

This approach to considering children's wishes in child custody disputes, although different in form, still has the same goal as the infancy doctrine, to protect children. An individualized approach to maturity is much easier to apply ex-ante, before any parties have relied on whether the minor is sufficiently mature. In a child custody dispute, adults unfamiliar with the minor do not need to evaluate the maturity of the minor before making legal choices, as would be required if a "mature" minor were given contracting ability. Rather, in the midst of an existing dispute, a judge, who also may require professional psychological assessments, ${ }^{154}$ is afforded plentiful input from parents in evaluating the minor's maturity to decide how much weight her preference will be given. ${ }^{155}$ Such assessments of maturity would be a wholly unworkable process in contract law. In that situation, a well-meaning adult's incorrect judgment would be penalized when a judge disagrees about the minor's capacity. A bright-line age of majority based on an objective fact permits adults to determine capacity to contract by requiring age verification or a good faith effort at verification. ${ }^{156}$

\section{E. Other Age-Based Legal Standards}

Many laws draw definitive lines based on age. The majority of agebased protections cover those under age eighteen, as does the infancy doctrine. For example, voting age is eighteen. ${ }^{157}$ The list also includes prohibitions on gambling ${ }^{158}$ and driving without parental consent. ${ }^{159}$

152. O’Neill, supra note 147, § 2(a).

153. See, e.g., Kelly v. Kelly, 640 N.W.2d 38, 45 (N.D. 2002) ("The preference of the children 'can be an important factor to consider when determining the best interests of the child."' (quoting Loll v. Loll, 561 N.W.2d 625, 629 (N.D. 1997))).

154. Joel E. Smith, Annotation, Right to Require Psychiatric or Mental Examination for Party Seeking to Obtain or Retain Custody of Child, 99 A.L.R.3D 268 § 3(a) (1980).

155. See O’Neill, supra note 147, § 15 (discussing cases that place the right of a natural parent above a child's wishes to be in the custody of a guardian).

156. The defenses available to adults who are fraudulently misled by minors in the attempt to verify age are discussed in Preston \& Crowther, supra note 6, at 59-62.

157. Thompson v. Oklahoma, 487 U.S. 815, app. A (1988) (plurality opinion).

158. Id. at 395 ("Where gambling is legal, adolescents under 18 are generally not permitted to participate in it.”).

159. Stanford v. Kentucky, 492 U.S. 361, 394-95 (1989) (“Thirty-four states require parental 
Minors do not have a Second Amendment right to bear arms. ${ }^{160}$ Additionally, some states prohibit employing minors during school hours ${ }^{161}$ and body piercing or tattooing minors. ${ }^{162}$ Most states prohibit selling pornographic material to individuals under age seventeen. ${ }^{163}$

Of particular interest is that some legal standards are higher than age eighteen. For instance, the minimum drinking age is statutorily set at twenty-one in all states, ${ }^{164}$ and some states even have a minimum age for using tobacco products that is greater than eighteen. ${ }^{165}$ One of the latest examples is the Credit Card Accountability, Responsibility, and Disclosure (CARD) Act of 2009, which prohibits issuing credit cards to anyone under age twenty-one without an adult cosigner. ${ }^{166}$

These numerous age-based laws reinforce that protecting minors is still a prevalent part of our law. Across legal disciplines, these restrictions are fundamentally consistent. Where the law appears to depart from the norm of treating children as having a legal disability, such as specific instances where minors have been given greater decisional autonomy for medical decision-making, the underlying principle is still protecting minors rather than a statement that minors no longer need protection. A comparison across legal fields does not suggest the infancy doctrine is outdated.

\section{JUSTIFICATIONS FOR CATEGORICAL AGE DETERMINATIONS}

The infancy doctrine is predictable and easy to apply because it relies on a categorical, objectively measurable standard based on counting

consent before a person below 18 may drive a motor car.”), overruled in part by Roper v. Simmons, 543 U.S. 551 (2005).

160. Cheryl B. Preston, Zoning the Internet: A New Approach to Protecting Children Online, 2007 BYU L. REV. 1417, 1438 (2007).

161. Id.

162. Id

163. Stanford, 492 U.S. at 395 ("Legislation in 42 States prohibits those under 18 from purchasing pornographic materials.”).

164. Seymour Moskowitz, Save the Children: The Legal Abandonment of American Youth in the Workplace, 43 AKRon L. REV. 107, 145 (2010) (citing Ken Sternberg, Alcohol Consumer Must Be 21 Years Old in All States; Concerns Remain About Drunk Driving, 260 JAMA 2479, 2479 (1988)).

165. Id. \& n.279 (citing Ctrs. for Disease Control, State Laws on Tobacco Control-United States, 1998, 48 Morbidity \& Mortality WEEKLY ReP. 21, 26 (1999)) (stating that Alabama, Alaska, and Utah have set the minimum age at nineteen).

166. Annamaria Lusardi et al., Financial Literacy Among the Young, 44 J. ConsuMER AFF. 358, 360 (2010). For a critique of the CARD Act, see Andrew A. Schwartz, Old Enough to Fight, Old Enough to Swipe: A Critique of the Infancy Rule in the Federal Credit Card Act, 2011 UTAH L. REV. 407 (2011). 
eighteen years from a date of birth in a country where everyone has a birth certificate. ${ }^{167}$ Age or actual birthdates are included in drivers' licenses, school identifications, and other forms of identification. Of course, determining that all children become responsible as adults at eighteen is arbitrary. The infancy doctrine has been criticized because of its categorical age cutoff. Some argue that determinations of who should be treated as adults under the law should be resolved with a case-by-case approach. $^{168}$

As one commentator put it: "It is quizzical at best to grasp the concept that in the blink of an eye, a person sheds infancy and attains adulthood the moment the person's eighteenth birthday is realized.”169 Those who take this position generally support a rebuttable presumption of capacity for adolescents that would be subject to a factual inquiry of incapacity at the minors' request. ${ }^{170}$

Drawing the line at eighteen years of age is subject, of course, to the objections always raised against categorical rules. ${ }^{171}$ The qualities that distinguish juveniles from adults do not disappear when an individual turns eighteen. By the same token, some under age eighteen have already attained a level of maturity some adults will never reach. However, a line must be drawn. ${ }^{172}$

As a matter of constitutional law, categorical lines are perhaps not ideal nor necessary for determinations in a world of unlimited resources. But, the Supreme Court is quite clear that the age of minority requires a fixed line and that the line is appropriate at age eighteen. Recently, the Supreme Court in Graham v. Florida reaffirmed the constitutionality of statutory enactments relying on an arbitrary age cutoff. ${ }^{173}$ Quoting

167. Some states follow the common law method of granting adulthood the day before the eighteenth birthday. Preston \& Crowther, supra note 6, at 50 n.8. Currently the cutoff is generally at the minor's eighteenth birthday rather than the day before. $I d$.

168. See Brief for Petitioner at 33, Roper v. Simmons, 543 U.S. 551 (2005) (No. 03-633), 2004 WL 903158, at*33; see also supra Part III.D (discussing the individualized approach of family law).

169. Daniel, supra note 64, at 242.

170. E.g., Larry A. DiMatteo, Deconstructing the Myth of the "Infancy Law Doctrine": From Incapacity to Accountability, 21 OHIO N.U. L. REV. 481, 524 (1994) ("The right of disaffirmance as enunciated in the infancy law doctrine should be eliminated and replaced by a 'factors' test to determine if a minor lacked the capacity to contract."); see also Daniel, supra note 64, at 267-68 (proposing a rebuttable presumption of capacity for adolescents that would allow courts to investigate incapacity where alleged by the minor.

171. See, e.g., Schwartz, supra note 166, at 409 (“A bright-line rule is likely to be both overand underinclusive, but also predictable and inexpensive. A flexible standard may be more fair and accurate, but also more costly to administer and difficult to predict.” (internal citation omitted)).

172. Roper, 543 U.S. at 574.

173. Graham v. Florida, 130 S. Ct. 2011, 2030-34 (2010). 
Roper, the Graham Court was satisfied with age eighteen because it "is the point where society draws the line for many purposes between childhood and adulthood."

The choice of age eighteen is mirrored in the international context. ${ }^{175}$ The Roper Court noted that

Article 37 of the United Nations Convention on the Rights of the Child, which every country in the world has ratified save for the United States and Somalia, contains an express prohibition on capital punishment for crimes committed by juveniles under eighteen. No ratifying country has entered a reservation to the provision prohibiting the execution of juvenile offenders. Parallel prohibitions are contained in other significant international covenants. ${ }^{176}$

A categorical rule is appropriate here because, among other reasons, the differences in adolescents are a result of brain immaturity that cannot adequately be judged by a judge or a jury, ${ }^{177}$ let alone a party seeking a contract. In Roper, relying in part on evidence that psychiatrists are forbidden from diagnosing any patient under age eighteen as having certain disorders, the Court explained: "It is difficult even for expert psychologists to differentiate between the juvenile offender whose crime reflects unfortunate yet transient immaturity, and the rare juvenile offender whose crime reflects irreparable corruption.”" ${ }^{\text {"78 }}$ The Graham Court agreed with this rejection of the case-by-case approach. ${ }^{179}$ Even if some minors do have sufficient maturity to be treated as adults, "it does not follow that courts taking a case-by-case proportionality approach could with sufficient accuracy distinguish the few . . . from the many."180

Adults who have entered contracts with minors will try to enforce them by arguing that the minor in question is sufficiently mature to be liable. Even if courts could reasonably determine the maturity and capacity of judgment possessed by a minor at some prior time when she

\footnotetext{
174. Id. at 2016 (quoting Roper, 543 U.S. at 574).

175. Roper, 543 U.S. at 576.

176. Id. (citations omitted) (citing United Nations Convention on the Rights of the Child art. 37, Nov. 20, 1989, 1577 U.N.T.S. 3).

177. See Maroney, supra note 117, at 94 (“[B]ecause developmental neuroscience supports only probabilistic generalizations about youth as a class, it is unhelpful in making highly individualized determinations such as formation of intent.”).

178. Roper, 543 U.S. at 573 (citing Laurence Steinberg \& Elizabeth S. Scott, Less Guilty by Reason of Adolescence: Developmental Immaturity, Diminished Responsibility, and the Juvenile Death Penalty, 58 Am. PsycholOGIST 1009, 1014-16 (2003)).

179. Graham, 130 S. Ct. at 2031-32.

180. Id. at 2032.
} 
entered a contract, forcing minors into expensive litigation based on subjective, personal facts that must be interpreted by expensive experts trained in soft sciences would not necessarily reach better results. ${ }^{181}$ As one commentator noted:

An individualized system is not necessarily more effective at reducing the number of false positives or negatives. Rather, such a system may lead to greater uncertainty because a minor's rights and responsibilities are subject to the whims and assumptions of the particular factfinder who is assigned the minor's case.... The resulting uncertainty means that minors or the adults that must interact with them are not put on notice as to the former's legal status. ${ }^{182}$

Moreover, those who would benefit most from such an approach would be the repeat players: vendors and service providers that have thousands of contracts with minors and can afford protracted and expensive litigation to create a line of precedent to discourage invocation of the infancy doctrine. The minor who only wishes to avoid a contract once in her life could not afford to invest the significant time, money, and effort to establish precedent for future cases.

A legal system that determines the maturity of minors on a case-bycase basis would inevitably introduce problematic communication issues between minors and adults involved in the legal system. The Graham Court's concerns apply, at least with some force, to the experience of a minor in the civil legal system. Juveniles mistrust adults and have limited understanding of the legal system and the risks and benefits to weigh in making litigation decisions. "They are less likely than adults to work effectively with their lawyers" to resist liability based on claims of maturity. ${ }^{183}$ This difficulty in weighing long-term consequences and developing working relationships, along with a corresponding impulsiveness and reluctance to trust counsel, were all recognized by the Graham Court as likely to impair the quality of a juvenile defendant's representation. ${ }^{184}$ Introducing individualized liability to contracts will similarly systematically disadvantage minors.

181. See Cunningham, supra note 93, at 368-69.

182. Id.

183. Graham, 130 S. Ct. at 2032.

184. Id. 


\section{Core Principles Behind Protecting MinORS}

Supreme Court opinions interpreting the Constitution are a fruitful source for statements of foundational jurisprudential principles. Even in cases where the Supreme Court considers statutes subject to strict scrutiny, the Court categorically affirms the compelling governmental interest states have in protecting minors. ${ }^{185}$ In addition, the right of parents to maintain involvement in legal issues involving minors rises to constitutional protection, with the very narrow exceptions discussed above where the state becomes parens patriae. ${ }^{186}$ States are justified in limiting the ability of adults to enforce against minors legal obligations entered without parental or guardian approval. This Part examines the constitutional bases for protecting minors and supporting parents' discretion in the raising of their children.

\section{A. Compelling Interest in Protecting Minors}

This governmental interest exists in addition to the duties of parents as a matter of "society's transcendent interest in protecting the welfare of children." 187 The Supreme Court declared:

It is evident beyond the need for elaboration that a State's interest in "safeguarding the physical and psychological well-being of a minor" is "compelling." ... Accordingly, we have sustained legislation aimed at protecting the physical and emotional well-being of youth even when the laws have operated in the sensitive area of constitutionally protected rights. ${ }^{1}$

This concept, that minors are distinguished from adults even with respect to constitutional rights, ${ }^{189}$ was again reaffirmed in Reno $v$. ACLU. ${ }^{190}$ In

185. See, e.g., Ashcroft v. ACLU, 542 U.S. 656, 672-73 (2004) (striking down statute because it was not narrowly tailored for the compelling governmental interest of protecting minors from pornography); see also Reno v. ACLU, 521 U.S. 844, 863 n.30 (1997) (“Appellees also do not dispute that the Government generally has a compelling interest in protecting minors from 'indecent' and 'patently offensive' speech."). For further discussion of this compelling interest in the context of the Child Online Protection Act, see Preston, supra note 160.

186. See supra Part 0.0 .

187. People v. Kahan, 206 N.E.2d 333, 334 (N.Y. 1965) (Fuld, J., concurring).

188. New York v. Ferber, 458 U.S. 747, 756-57 (1982) (citations omitted).

189. At one point the Supreme Court reached toward recognizing a free speech right in minors attending public schools. Tinker v. Des Moines Indep. Cmty. Sch. Dist., 393 U.S. 503, 514 (1969). Critics assert that "Tinker's reasoning conflicted with the traditional understanding of the judiciary's role in relation to public schooling.” Morse v. Frederick, 551 U.S. 393, 417 (2007) (Thomas, J., concurring). However, the Court has since consistently distanced itself from Tinker, primarily by 
general, the Supreme Court has consistently held that "age is not a suspect classification under the Equal Protection Clause."191 The Louisiana Supreme Court agrees that age distinctions are subject only to a rational basis test and that "there is a rational basis for treating juveniles differently: to promote the interest and welfare of the child."192

\section{B. Compelling Interest in Parental Discretion}

Another constitutionally recognized compelling governmental interest is supporting parents' authority to raise their children in the manner they see fit. ${ }^{193}$ "[C]onstitutional interpretation has consistently recognized that the parents' claim to authority in their own household to direct the rearing of their children is basic in the structure of our society."194 As Professor Preston has discussed elsewhere, "the state respects parents' decisions regarding placing their children in private sectarian schools rather than public schools, placing them in schools that teach in languages other than English, and, at times, taking them out of school altogether.”195

If parents elect to restrict their teens from entering contracts, the government should honor that choice. Other adults should not override that choice by dealing independently with children without parental knowledge and involvement. Parents who believe that their child needs to assume the responsibility of a major purchase may cosign a contract or create interfamily transactions with whatever consequences they select.

\footnotetext{
making broad exceptions. See, e.g., Hazelwood Sch. Dist. v. Kuhlmeier, 484 U.S. 260, 270 (1988); Morse, 551 U.S. at 397; Bethel Sch. Dist. No. 403 v. Fraser, 478 U.S. 675, 685-86 (1986).

190. 521 U.S. at 864-65 (quoting Ginsberg v. New York, 390 U.S. 629, 636 (1968)).

191. Gregory v. Ashcroft, 501 U.S. 452, 470 (1991).

192. Recent Court Decisions and Legislation Impacting Juveniles, 14 U.C. DAVIS J. JuV. L. \& POL'Y 403, 421 (2010) (reviewing In re State ex rel. A.J., 27 So. 3d 247 (La. 2009)).

193. See Ginsberg, 390 U.S. at 639; Prince v. Massachusetts, 321 U.S. 158, 166 (1944); see also Sheerin N.S. Haubenreich, Parental Rights in Myspace: Reconceptualizing the State's Parens Patriae Role in the Digital Age, 31 HASTings Comm. \& ENT. L.J. 223, 227 (2009) ("Nearly a century of cases [has established] an incontrovertible right to raise one's child in any manner, subject to very few limitations.").

194. Ginsberg, 390 U.S. at 639.

195. Preston, supra note 160, at 1441 (citation omitted) (citing Pierce v. Soc’y of Sisters, 268 U.S. 510 (1925); Meyer v. Nebraska, 262 U.S. 390 (1923); Sch. Dist. of Grand Rapids v. Ball, 473 U.S. 373 (1985); Wisconsin v. Yoder, 406 U.S. 205 (1972)).
} 
[Vol. 61

\section{THE PROVINCE OF LEgISLATURES}

The age of majority is set by statute in every state, and most state statutes expressly recognize the contract infancy doctrine. Any change to this standard should be made by the state legislatures, ${ }^{196}$ rather than by courts writing in exceptions, misconstruing language, or ignoring established doctrine, or by Restatement drafters selecting a slim minority position. Policy decisions based on changing consensus in attitudes about adolescents are the province of the state legislatures. ${ }^{197}$ As the Supreme Court has declared, "the basic line-drawing process... is 'properly within the province of legislatures, not courts.",198 Legislatures are far better equipped than the judiciary to handle determinations about the capacities and protections of minors because they are not limited by a case-or-controversy requirement and "an adversary context," 199 and instead can independently investigate societal attitudes and explore a variety of solutions.

The infancy doctrine has been well established in the law since the 1500 s. $^{200}$ State legislatures reduced the age of majority from the historical twenty-one to eighteen in the 1970s, and some have customized some of the defenses and exceptions. Failing to make other changes is indicative of a continuing consensus on the doctrine. ${ }^{201}$ Such long-standing consistency in state law "provides an additional reason for [a] court to be very hesitant before dabbling in matters involving such

196. See Halbman v. Lemke, 298 N.W.2d 562, 567 (Wis. 1980) (“[M]odifications of the rules governing the capacity of infants to contract are best left to the legislature.”); Kiefer v. Fred Howe Motors, 158 N.W.2d 288, 290 (Wis. 1968) (“[A]ppelant might better seek the change [to the infancy doctrine] it proposes in the legislative halls rather than this court.”); Cunningham, supra note 93, at 369 ("[L]egislative action is the best way to resolve the current conflicts in the law regarding children.”).

197. See, e.g., Casella v. SouthWest Dealer Servs., Inc., 69 Cal. Rptr. 3d 445, 454 (Cal. Ct. App. 2007) (quoting Gantt v. Sentry Ins., 824 P.2d 680, 687-88 (Cal. 1992)); Hous. Auth. of Macon v. Ellis, 655 S.E.2d 621, 623 (Ga. Ct. App. 2007) (citing Commonwealth Inv. Co. v. Frye, 134 S.E.2d 39 (Ga. 1963)); Haskin v. Ne. Airways, Inc., 123 N.W.2d 81, 86 (Minn. 1963); Skyline Village Park Ass'n v. Skyline Village L.P., 786 N.W.2d 304, 311 (Minn. Ct. App. 2010); Pannozzo v. Anthem Blue Cross \& Blue Shield, 787 N.E.2d 91, 99 (Ohio Ct. App. 2003).

198. Hutto v. Davis, 454 U.S. 370, 374 (1982) (quoting Rummel v. Estelle, 445 U.S. 263, 27576 (1980))

199. GTE Sylvania, Inc. v. Consumers Union of U.S., 445 U.S. 375, 382-83 (1980) (citing Flast v. Cohen, 392 U.S. 83, 95 (1968)).

200. Preston, supra note 1 , at 232.

201. See Watson v. J.C. Penney Co., 605 N.E.2d 723, 725 (Ill. App. Ct. 1992) (“[W]e conclude that the legislature, by not amending the 60 -year-old natural accumulation rule, has indicated its present satisfaction with that rule.”). 
fundamental policy questions."202 Simply put, "the courts ought not change an established legal doctrine," ${ }^{203}$ by implying exceptions and reinterpreting statutory language or otherwise.

Trends of the past few decades suggest that if legislatures were to move the line, the cutoff age would likely increase, not decrease. ${ }^{204}$ The age at which people are marrying has risen over the past few decades, and young adults increasingly rely upon parental support beyond the age of eighteen. ${ }^{205}$ The recently enacted federal CARD Act of 2009 included an age disability until twenty-one. ${ }^{206}$ The only Supreme Court statements on adolescence in recent years have tightened the protections for minors rather than loosen them. ${ }^{207}$

\section{VII.CONCLUSION}

The intricacies of the contract infancy doctrine may need reconsideration for the digital age. This process is the province of state legislatures. In any event, the doctrine should not be abandoned for irrelevant reasons. Claims of inconsistencies with the law governing minors in tort, criminal law, healthcare law, family law, and other arenas are invalid. These schemes may include more detailed analysis of minors' responsibility or input based on particularized concerns arising from the nature of the legal interests represented in each field. But these interests do not align with the interests in contract law. Moreover, any movement in these areas is still inextricably tied to concepts of minors' vulnerabilities and inappropriate pressure from adults in various quarters.

Further, any change in the infancy doctrine cannot be justified by the fact that the age cutoff is a fixed, objective date rather than a measure of

\footnotetext{
202. Id.

203. James v. Hutton, 373 S.W.2d 167, 168 (Mo. Ct. App. 1963).

204. See Ann Coulter, Repeal the 26th Amendment!, AnNCOUlter.Com (Nov. 10, 2010), http://www.anncoulter.com/columns/2010-11-10.html (suggesting that the Twenty-sixth Amendment should be repealed to raise the voting age based in part on "[b]rain research in the last five years at Dartmouth and elsewhere [that] has shown that human brains are not fully developed until age 25 and are particularly deficient in their frontal lobes, which control decision-making, rational thinking, judgment, the ability to plan ahead and to resist impulses.”). But see Rodney Skager, Extending Childhood into the Teen Years: "Infantilization" and Its Consequences, REClaiming ChILD. \& Youth, Summer 2009, at 20 (suggesting that "pronouncements that adolescence extends as far as the late 20s" exacerbates "problems experienced or caused by adolescents").

205. Preston \& Crowther, supra note 14.

206. 15 U.S.C.A. § 1637(c)(8) (West Supp. 2012).

207. See Graham v. Florida, 130 S. Ct. 2011 (2010); Roper v. Simmons, 543 U.S. 551 (2005).
} 
relative maturity. A legislature may decide the costs of litigating the individual characteristics of a particular minor is justified by the enormity of the issues in some contexts, notwithstanding the systemic prejudice against minors in such litigation. However, the Supreme Court's decisions that imposing the death penalty and life without parole on minors, even if murder charges are involved, be based on a categorical age line surely suggests that no contract-related dispute warrants a more complex individual inquiry. Protecting minors is a constitutionally recognized compelling interest of the state and such statutes are subject only to a rational basis analysis. No jurisprudential principles justify a court or the drafters of the Restatement (Third) of Restitution and Unjust Enrichment in rewriting centuries of contract doctrine based on a notion of injustice to adults. 